\title{
SURFACE VERSUS UNDERGROUND MEASUREMENTS OF ACTIVE TECTONIC DISPLACEMENTS DETECTED WITH TM 71 EXTENSOMETERS IN WESTERN SLOVENIA
}

\author{
PRIMERJAVA POVRŠINSKIH IN PODZEMELJSKIH MERITEV \\ AKTIVNIH TEKTONSKIH PREMIKOV DOLOČENIH S TM 71 \\ EKSTENZIOMETRI V ZAHODNI SLOVENIJI
}

\author{
Andrej GOSAR ${ }^{1,2}$, Stanka ŠEBELA³, Blahoslav KOŠŤÁKK ${ }^{4}$ \& Josef STEMBERK ${ }^{4}$
}

\begin{abstract}
UDC 551.24(497.4-15)

Andrej Gosar, Stanka Šebela, Blahoslav Košták \& Josef Stemberk: Surface versus underground measurements of active tectonic displacements with TM 71 exstensometers in Slovenia

The tectonic setting of W Slovenia is characterised by NW-SE trending dextral strike-slip fault systems and moderate seismicity. Monitoring of tectonic movements along five presumably active faults or in their vicinity using TM 71 extensometers was set up in 2004. In five years of monitoring some clear trends of displacement were established. The morphologically most prominent fault in W Slovenia is Idrija Fault having a total length of more than $120 \mathrm{~km}$. The average lateral displacement measured along a crack in its inner fault zone in Učja valley was $0.26 \mathrm{~mm} /$ year. Short-term rates were even greater and reached $0.54 \mathrm{~mm} /$ year. Raša Fault monitoring site at the foot of Vremščica Mt. established first an average uplift of SW block for $0.16 \mathrm{~mm} /$ year and left-lateral displacement of $0.16 \mathrm{~mm} /$ year. It was followed by down-slip of the same block at the rate of $0.37 \mathrm{~mm} /$ year. In Postojnska Jama two instruments, $260 \mathrm{~m}$ apart, were installed at the fault zone, which extends about 1 $\mathrm{km}$ northeast from Predjama Fault. We detect small tectonic deformations, dextral horizontal movement of $0.05 \mathrm{~mm}$ in 5 years for Postojna 1 and extension of $0.03 \mathrm{~mm}$ in 5 years for Postojna 2. Both devices recorded similar reactions to some earthquakes with magnitude range 3.1-5.2 and epicentral distance of $12-95 \mathrm{~km}$. The amplitude of individual peaks is in the order of $0.08 \mathrm{~mm}$. The monitoring at Kneža Fault started at the end of 2006. In two years clear oblique displacement was established with left-lateral rate of $0.06 \mathrm{~mm} /$ year and uplift of SW block for $0.06 \mathrm{~mm} /$ year. Monitoring in Pološka Jama situated in vicinity of the Ravne Fault started in 2008. Preliminary results show $0.08 \mathrm{~mm}$ of horizontal displacement between two
\end{abstract}

Izvleček

UDK 551.24(497.4-15)

Andrej Gosar, Stanka Šebela, Blahoslav Košták \& Josef Stemberk: Primerjava površinskih in podzemeljskih meritev aktivnih tektonskih premikov določenih s TM 71 ekstenziometri $v$ zahodni Sloveniji

Za tektonsko zgradbo zahodne Slovenije so značilni sistemi desnozmičnih prelomov usmerjeni NW-SE in zmerna potresna dejavnost. Leta 2004 smo pričeli z meritvami tektonskih premikov z ekstenziometri TM 71 ob petih domnevno aktivnih prelomih ali v njihovi bližini. $V$ petih letih opazovanj smo ugotovili nekatere jasne trende premikov. Morfološko najmočneje izražen prelom v zahodni Sloveniji je Idrijski prelom, ki je dolg preko $120 \mathrm{~km}$. Na razpoki v njegovi notranji coni v dolini Učje smo ugotovili povprečne zmične premike $0,26 \mathrm{~mm} / \mathrm{leto}$. Kratkotrajnejše hitrosti so še večje in dosežejo $0,54 \mathrm{~mm} / \mathrm{leto}$. $\mathrm{Na}$ Raškem prelomu v vznožju Vremščice smo ugotovili najprej dvigovanje SW bloka za $0,16 \mathrm{~mm} /$ leto in levozmične premike $\mathrm{s}$ hitrostjo $0,16 \mathrm{~mm} /$ leto. Sledilo je pogrezanje istega bloka za $0,37 \mathrm{~mm} / \mathrm{leto}$. V Postojnskem jamskem sistemu smo na razdalji $260 \mathrm{~m}$ namestili dva inštrumenta na prelomni coni, ki poteka okoli $1 \mathrm{~km}$ severovzhodno od Predjamskega preloma. Beležimo majhne tektonske premike, desni zmik za $0,05 \mathrm{~mm}$ v petih letih za Postojno 1 in ekstenzijo velikosti $0,03 \mathrm{~mm}$ v petih letih za Postojno 2. Oba ekstenziometra sta se podobno odzvala na nekatere potrese $\mathrm{z}$ magnitudami $\mathrm{v}$ območju 3.1-5.2 in epicentralno oddaljenostjo $12-95 \mathrm{~km}$. Amplituda posameznih vrhov je reda velikosti $0,08 \mathrm{~mm}$. Opazovanje na Knežkem prelomu se je pričelo konec 2006. V dveh letih smo izmerili poševno zmikanje $\mathrm{z}$ desnozmično hitrostjo $0,06 \mathrm{~mm} /$ leto in dvigovanje SW bloka za $0,06 \mathrm{~mm} /$ leto. Opazovanje v Pološki jami, ki se nahaja v bližini Ravenskega preloma se je začelo v letu 2008. Preliminarni rezultati kažejo horizontalni premik $0,08 \mathrm{~mm}$ med

\footnotetext{
${ }^{1}$ Environmental Agency of the Republic of Slovenia, Seismology and Geology Office, Dunajska 47, Ljubljana, Slovenia, e-mail: andrej.gosar@gov.si

${ }^{2}$ University of Ljubljana, Faculty of Natural Sciences and Engineering, Aškerčeva 12, 1000 Ljubljana, Slovenia

${ }^{3}$ Karst Research Institute ZRC SAZU, Titov trg 2, 6230 Postojna, Slovenia, e-mail: sebela@zrc-sazu.si

${ }^{4}$ Institute of Rock Structure and Mechanics, Academy of Sciences of the Czech Republic, V Holešovičkách 41, 18209 Prague, Czech Republic, e-mail: Stemberk@irsm.cas.cz
}

Received/Prejeto: 30.06.2009 
limestone beds. Established displacements proved the active tectonic movement of all monitored faults. Observed deformation rates can be compared with the regional deformation rate in W Slovenia established from GPS measurement, which is in the order of $2 \mathrm{~mm}$ /year

Keywords: micro-tectonic displacements, 3D monitoring, TM 71 extensometer, Idrija Fault, Raša Fault, Kneža Fault, Predjama Fault, Ravne Fault, Slovenia. dvema plastema apnenca. Ugotovljeni premiki dokazujejo aktivni tektonski značaj vseh opazovanih prelomov. Opazovane hitrosti deformacij lahko primerjamo s stopnjo regionalnih deformacij v zahodni Sloveniji ugotovljeno z GPS meritvami, ki so reda velikosti $2 \mathrm{~mm} / \mathrm{leto}$.

Ključne besede: mikro-tektonski premiki, 3D monitoring, ekstenziometer TM 71, Idrijski prelom, Raški prelom, Knežki prelom, Predjamski prelom, Ravenski prelom, Slovenija.

\section{INTRODUCTION}

Monitoring of tectonic deformations, as well as landslide movements and stability of mine walls with 3D extensom-

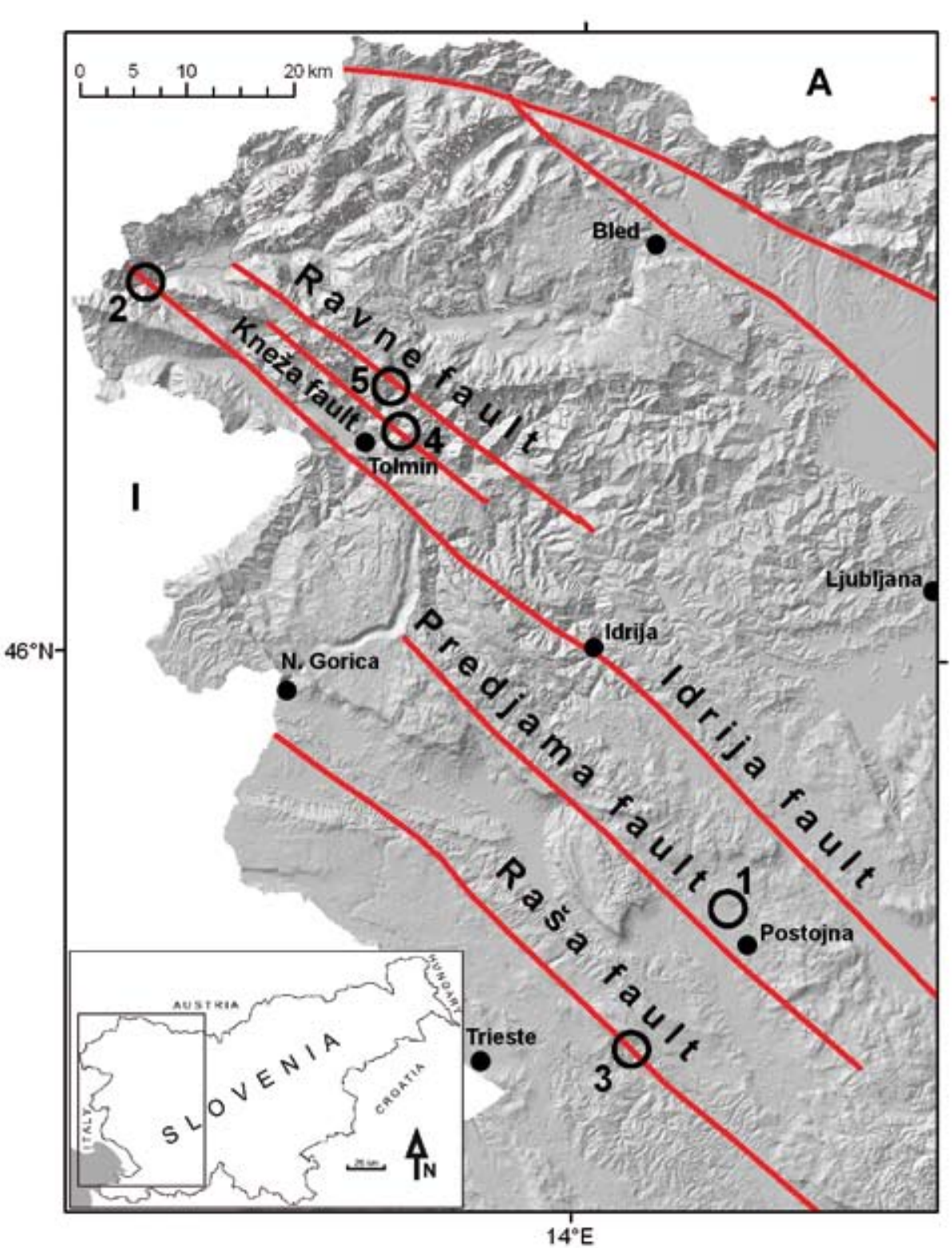

eter for in-situ monitoring (model TM 71) has been practised for more than 30 years (Koš̀ták 1969, 1977, 1991, 1998, 2002; Košták et al. 2007). Karst caves and artificial tunnels are very suitable for TM 71 installation due to the stable temperature conditions. Such cases are in the Czech Republic (Stemberk et al. 2008a), Poland (Kontny et al. 2005, Mąkolski et al. 2008), Slovakia (Briestenský et al. 2007) and Slovenia (Šebela \& Gosar 2005; Šebela 2005; Gosar 2007a; Gosar et al. 2007; Šebela et al. 2005; Šebela et al. 2008; Šebela 2009; Šebela et al. 2009). In Germany (Stemberk et al. 2003; Stemberk et al. 2008a) and in Slovakia the instruments are placed in artificial tunnels. On the Gargano peninsula (Italy) TM 71 is situated in the basement between the house wall and Mattinata fault plane (Borre et al. 2003). Monitoring of the surface outcrops is organized in Peru, Italy (Stemberk et al. 2003), Greece, Czech Republic, Slovakia, Slovenia (Gosar 2007a), etc.

Fig. 1: TM 71 monitoring sites in $W$ Slovenia and most important faults. 1-Postojnska Jama, 2-Učja, 3-Vremščica, 4-ZadlazČadrg, 5-Pološka Jama. 


\begin{tabular}{|l|l|l|l|l|}
\hline MONITORING SITE & $\begin{array}{l}\text { GEOLOGICAL } \\
\text { STRUCTURE }\end{array}$ & $\begin{array}{l}\text { DISTANCE TO IMPORTANT REGIONAL } \\
\text { TECTONIC STRUCTURE }\end{array}$ & $\begin{array}{l}\text { MONITORING } \\
\text { FROM }\end{array}$ & A.S.L. (M) \\
\hline Učja & Idrija Fault NW-SE & within Idrija Fault & 2004 & 420 \\
\hline Vremščica & Raša Fault NW-SE & within Raša Fault & 2004 & 620 \\
\hline Zadlaz-Čadrg & Kneža Fault NW-SE & within Kneža Fault & 2006 & 530 \\
\hline Postojna 1 & fault zone NW-SE & 1 km north from Predjama Fault & 2004 & 560 \\
\hline Postojna 2 & fault zone NW-SE & 1 km north from Predjama Fault & 2004 & 526 \\
\hline Pološka Jama & $\begin{array}{l}\text { bedding plane } \\
(120 / 40)\end{array}$ & $\begin{array}{l}300 \text { m south from Ravne Fault NW-SE } \\
\text { and 200 m above Julian Alps thrust }\end{array}$ & 2008 & 735 \\
\hline
\end{tabular}

Tab. 1: TM 71 monitoring sites in W Slovenia.

Monitoring of micro-displacements in W Slovenia is organized with six TM 71 instruments (Tab. 1). Three of them are located on the surface and three in karst caves (Fig. 1). Monitoring sites were selected in the seismically active areas, in the vicinity of regionally important faults and representative outcrops within fault zones.

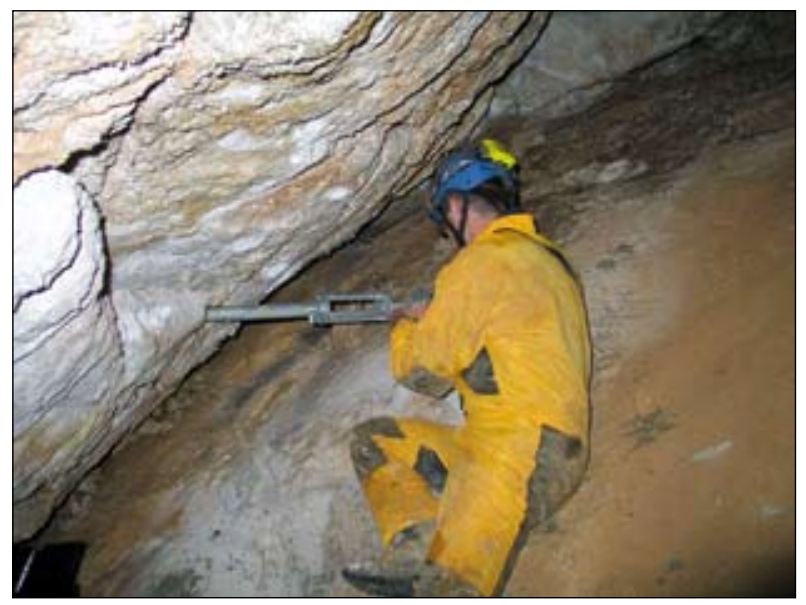

Fig. 2: Pološka Jama, TM 71 monitoring between two limestone beds dipping towards SE (Photo: S. Šebela).

In November 2004 two TM 71 extensometers were installed on the surface, one on Raša Fault zone at the SE foot of Vremščica Mountain and other on Idrija Fault in Učja valley. In November 2006 the third surficial instrument was set up on Kneža Fault (Zadlaz-Čadrg).
All three instruments are installed on Dinaric-oriented (NW-SE) regionally important faults in W Slovenia (Gosar 2007a).

In two Slovene karst caves (Postojnska Jama and Pološka Jama) three TM 71 instruments are installed. The monitoring of micro-tectonic movements in Postojnska Jama started on $26^{\text {th }}$ May 2004 (Postojna 1) and on $26^{\text {th }}$ February 2004 (Postojna 2). Two instruments, being $260 \mathrm{~m}$ apart, are installed on Dinaric-oriented (NW-SE) fault zone. The studied fault zone is situated about $1 \mathrm{~km}$ northeast from regionally important Dinaric-oriented Predjama Fault and about $5 \mathrm{~km}$ south from Idrija Fault.

Pološka Jama is situated about $300 \mathrm{~m}$ south from Ravne Fault. An instrument is installed between two sliding limestone beds (Fig. 2), about $50 \mathrm{~m}$ inside the cave from its SE entrance. Monitoring has taken place from $19^{\text {th }}$ June 2008.

All six monitoring sites in Slovenia are situated in karst areas, even though our idea was not limited only to the karst areas, but mostly to good outcrops within accessible fault zones. The results of regular monitoring show interesting rates and directions, but for Pološka Jama we can only speak of preliminary results due to short-term monitoring.

Comparison of displacements between surface versus underground monitoring sites was accomplished to evaluate displacements to see if the observed tectonic structure is active and in what scale are the movements, and for eventual coincidence with earthquakes. All sites show active tectonic micro-movements.

\section{STRUCTURAL GEOLOGY}

Slovenia is characterized by complex and neotectonically active geological setting at the border between Adria microplate and Eurasia plate. Studied area is part of Adria microplate south from Periadriatic Fault. Paleomagnet- ic data indicate about $30^{\circ}$ counterclockwise rotation of Adria microplate (Márton et al. 2003) since the late Miocene to Pliocene. 
Vrabec and Fodor (2006) described geologic structures during Miocene to recent times. Among thrust belts along the Adria margin are included Dinaric thrust systems, South-Alpine thrust system and Dinaric faults. Dinaric thrust systems are post-Eocene, representing NW-SE striking fold-and-thrust belt that can be followed from Istra towards central Slovenia (Vrabec \& Fodor 2006). They belong to External Dinarides that are characterised by moderate historic and recent seismicity.

The S- to SE-verging fold-and-thrust-belt of the Southern Alps formed in the Miocene (Vrabec \& Fodor 2006). The so-called Dinaric faults cut and displace both Dinaric and South-Alpine fold-and-thrust structures. Many Dinaric faults, including Idrija Fault, formed as dip-slip normal faults and were only later dextrally reactivated (Vrabec \& Fodor 2006).

It seems that a large part of regional deformation is still concentrated on Periadriatic Fault as long-lived structural system, whereas the younger structures south of it, such as Dinaric faults, have a comparatively minor role (Vrabec \& Fodor 2006).

Placer (2008) proposed the tectonic subdivision of Slovenia into: Adriatic-Apulian foreland, Dinarides, Southern Alps, Eastern Alps, and Pannonian basin. Vremščica and Postojna TM 71 monitoring sites are located within External Dinarides. Učja, Zadlaz-Čadrg and Pološka Jama sites can be found inside Southern Alps.

Recent activity of important regional faults in Slovenia was in recent years studied a great deal by different methods. Ravne Fault and Idrija Fault show signs of active tectonic movements (Cunningham et al. 2006; Rižnar et al. 2007; Komac \& Bavec 2007; Kastelic et al. 2008; Milanič et al. 2009). Raša Fault, Southalpine Front and Julian Alps thrust are identified as active regarding the vertical component of displacement (Rižnar et al. 2007).

\section{SEISMICITY OF W SLOVENIA}

The territory of Slovenia is considered as one of moderate and diffuse seismicity. Only few earthquakes can be directly related to known faults, because the extent of faults from the surface to the hypocentral depths is poorly known. Most earthquakes occur in a depth range between 5 and $20 \mathrm{~km}$. No surface rupture related to an earthquake has been detected so far in Slovenia (Poljak et al. 2000). The northern part of W Slovenia belongs to the tectonic unit of Southern Alps and the southern part to the External Dinarides. For both units moderate historical and recent seismicity is characteristic (Fig. 3). The strongest earthquake ever recorded in the Alps-Dinarides junction was the 1511 western Slovenia earthquake $(M=6.8)$. The exact location and mechanism of this event are still debated (Fitzko et al. 2005). The strongest post-1511 event happened in 1926 at the south-eastern part of Idrija Fault (Cerknica earthquake, $10 \mathrm{~km}$ east from Postojnska Jama) with magnitude of 5.6 (Poljak et al. 2000).
Most earthquakes in SW Slovenia are situated along Raša and Idrija Faults, delineated in NW-SE direction (Michelini et al. 1998). Their focal mechanisms indicate mainly right-lateral or reverse deformations (Poljak et al. 2000). Although strike-slip and thrust-type dominate, there are also a few earthquakes with normal-type faulting. From the fault plane solutions it is evident that the governing stress in the region runs approximately in N-S direction (Poljak et al. 2000).

The region of NW Slovenia undergoes a recent increase in seismic activity with two damaging earthquakes in the Upper Soča valley. The $12^{\text {th }}$ April $1998(\mathrm{Mw}=5.6)$ and $12^{\text {th }}$ July $2004(\mathrm{Mw}=5.2)$ earthquakes (Gosar 2007b) occurred on the NW-SE trending near-vertical Ravne Fault in the Krn mountains at 7-9 km depth. The focal mechanisms of both earthquakes show almost pure dextral strike-slip (Kastelic et al. 2008).

\section{METHODOLOGY}

TM 71 is a mechanical extensometer designed for installation on narrow cracks (crack gauging) to monitor relative micro-displacements between both walls of the crack. The sensitivity of the instrument is $0.05-0.0125$ $\mathrm{mm}$ in all three space co-ordinates and $3.2 \times 10-4 \mathrm{rad}$ in angular deviations (Stemberk et al. 2003). It measures the displacements in three dimensions $(x, y$ and $z)$ - displacement vector in two perpendicular planes (horizontal and vertical) and angular deviation (rotation). The measurement works on the principle of Moiré optical effect of two optical grids. Their interference pattern changes when two transparent plates move (Košták 1977, 1991). 


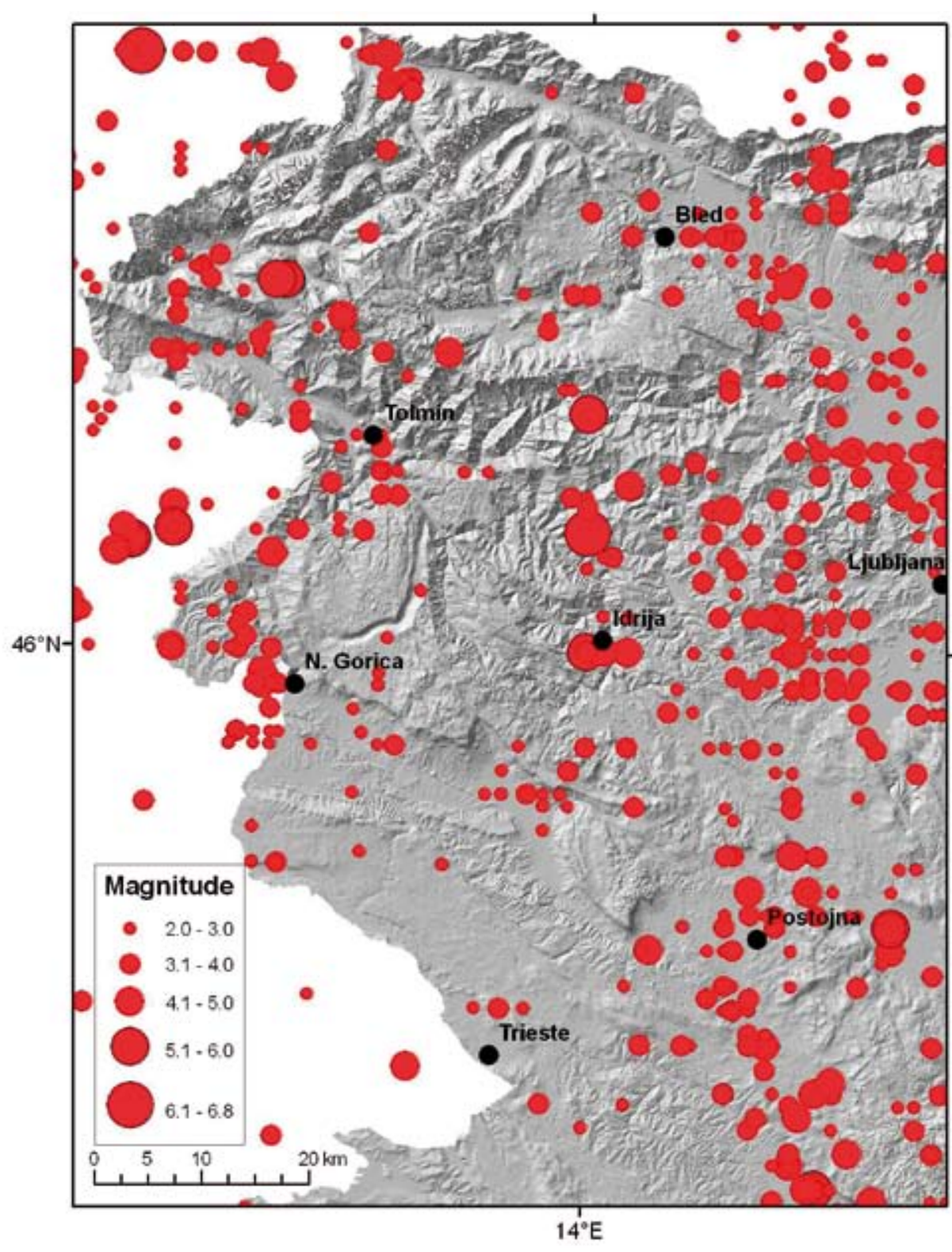

Fig. 3: Seismicity of W Slovenia (EARS catalogue for the period 567-2008).
The advantages of this purely opto-mechanical instrument are: it completely avoids the use of electrical transmission means and furnishes good performances under severe outdoor conditions, and it has a long-term stability.

The graphs (Figs. 4-8) represent the results of the movements in three coordinates $x, y$ and $z$, where $+x$ represents compression of the observed fault ( $-x$ extension), $+y$ represents sinistral horizontal movement ( $-y$ dextral) and $+z$ vertical movement.

Data are generally taken once a month or bimonthly and long-term monitoring is preferable. Temperature of the monitoring site is also taken into account for eventual temperature influence on the TM 71 instruments especially for surface outcrops. With regular monitoring of displacements we want to ascertain if the studied fault zone is still tectonically active and in what scale and direction are the movements. In W Slovenia, measurements were taken once a month or bimonthly only in Postojnska and Pološka Jama, and on other locations once every three months or even sparser.

\section{RESULTS AND DISCUSSION}

\section{SURFACE MONITORING}

\section{Idrija Fault}

The best morphologically expressed fault in the region of W Slovenia is Idrija Fault (Fig. 1), which extends from the Italian border near Bovec to Croatia in Gorski Kotar (N of Rijeka), having a total length of more than $120 \mathrm{~km}$. The strongest historical earthquake in the region, the »Idrija " earthquake in 1511 with estimated magnitude of 6.8 and max. intensity $\mathrm{X}$, is usually related to this fault (Ribarič 1979), but its exact location and relation to the faults in the region are still not clear (Fitzko et al. 2005). The second strongest known event, with magnitude 5.6, happened in 1926 at the SE part of the 

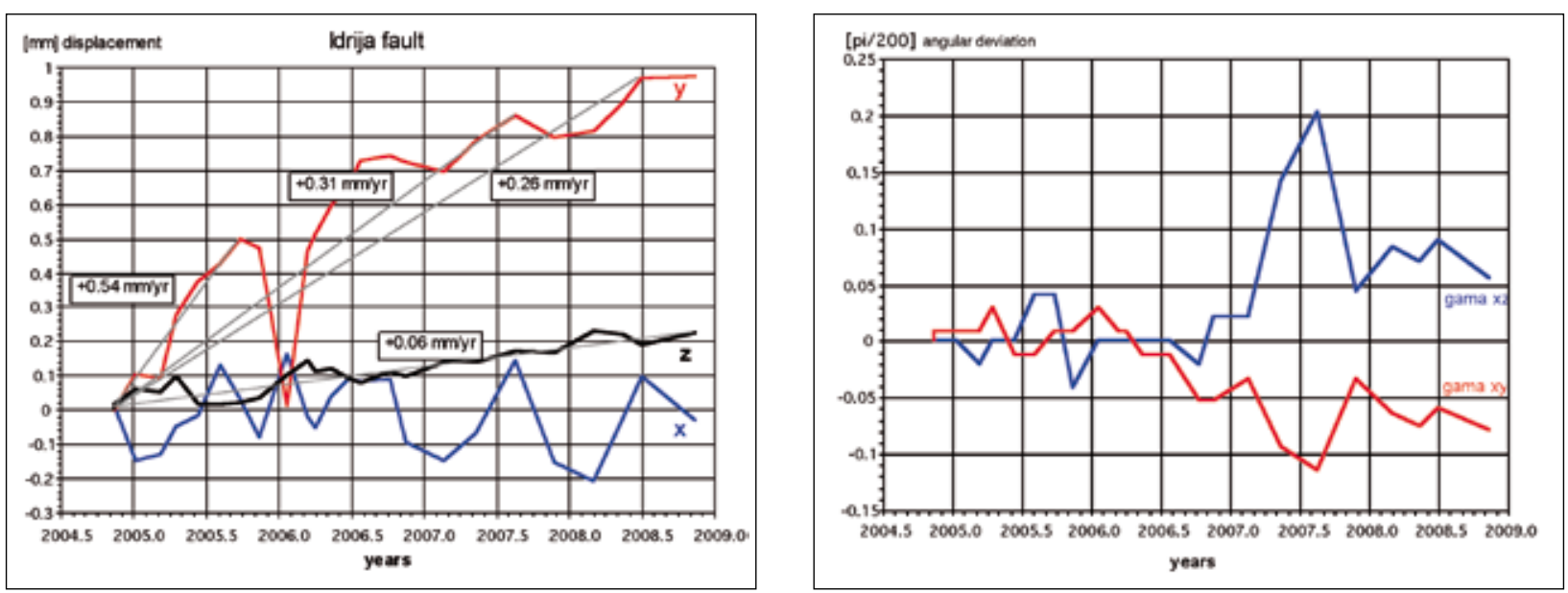

Fig. 4: Relative displacements ( $+x$ compression ( $-x$ extension), $+y$ sinistral horizontal movement $(-y$ dextral) and $+z$ down-slip of SW block ( $-z$ uplift)) and angular deviation detected with TM 71 exstensometer for Idija Fault (Učja).
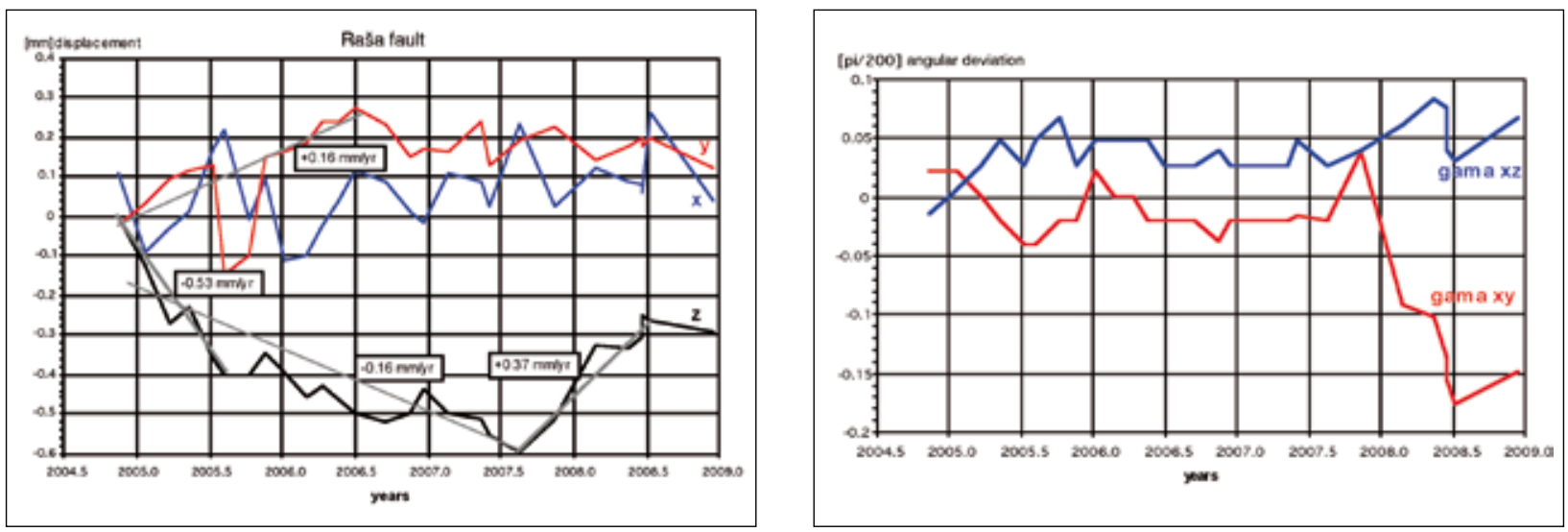

Fig. 5: Relative displacements ( $+x$ compression ( $-x$ extension), $+y$ sinistral horizontal movement $(-y$ dextral) and $+z$ down-slip of SW block ( $-z$ uplift)) and angular deviation detected with TM 71 exstensometer for Raša Fault (Vremščica).
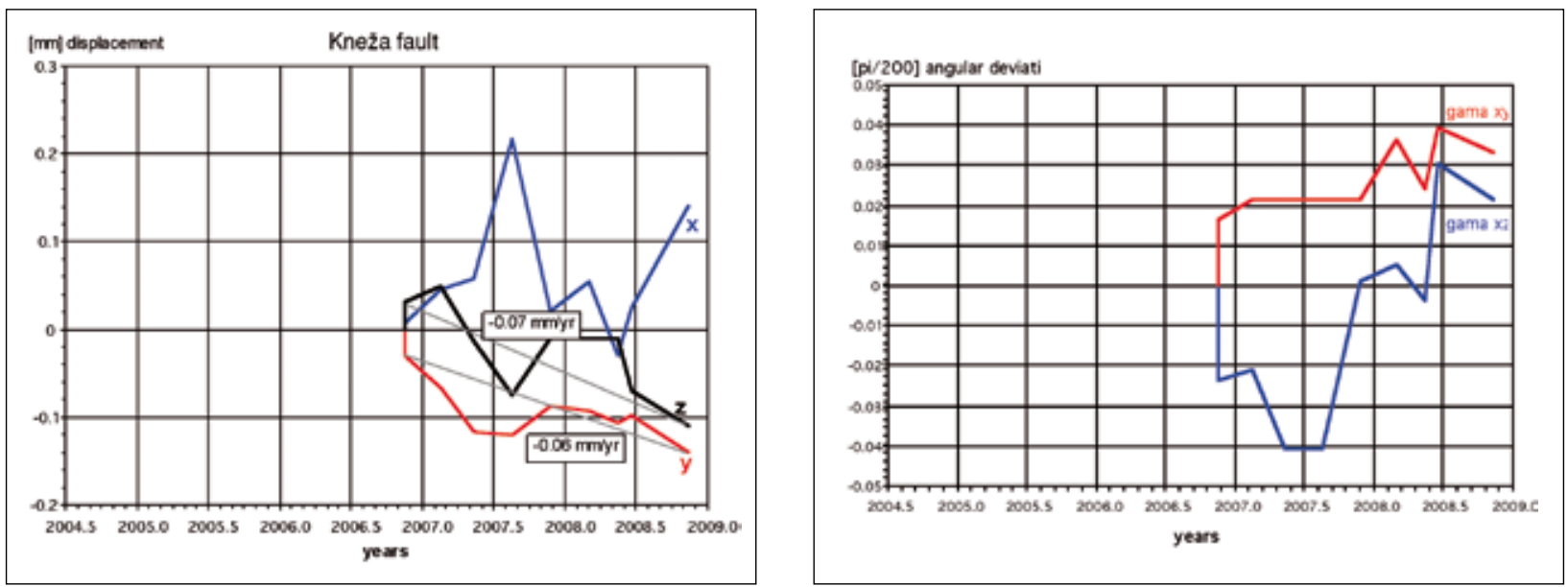

Fig. 6: Relative displacements ( $+x$ compression ( $-x$ extension), $+y$ sinistral horizontal movement $(-y$ dextral) and $+z$ down-slip of SW block (-z uplift)) and angular deviation detected with TM 71 exstensometer for Kneža Fault (Zadlaz-Čadrg). 

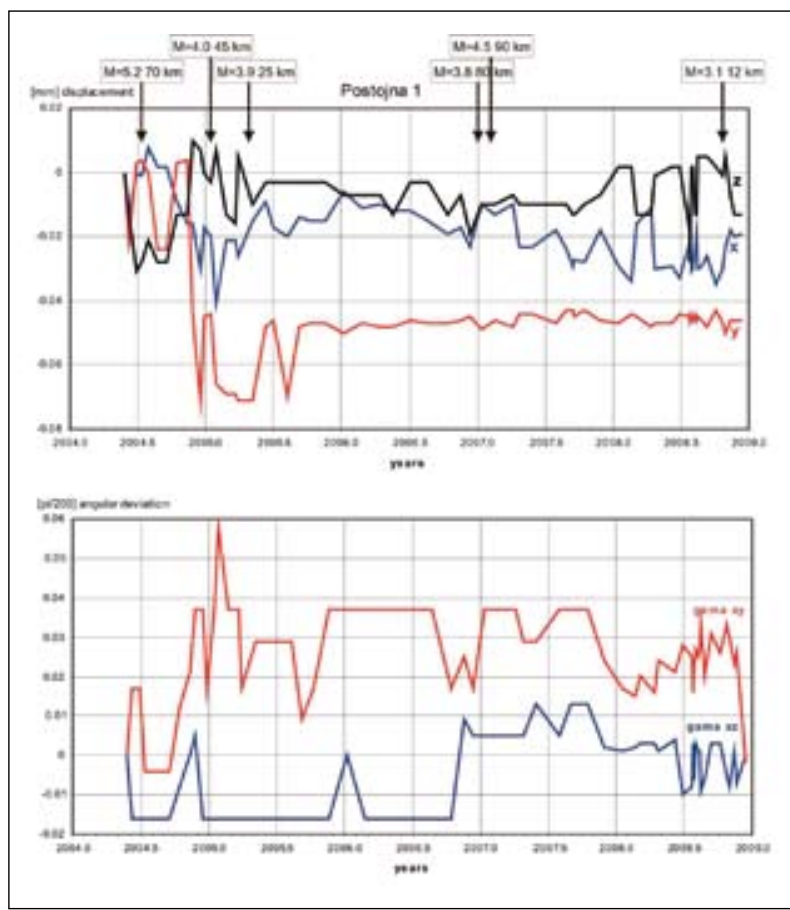

Fig. 7: Relative displacements ( $+x$ compression ( $-x$ extension), $+y$ sinistral horizontal movement ( $-y$ dextral) and $+z$ down-slip of northern block ( $-z$ uplift)) and angular deviation detected with TM 71 exstensometers for Postojna 1 with strongest earthquakes (magnitude and distance of epicentre, Tab. 2).

Idrija fault. However, recent seismicity in the vicinity of this fault is rather low (Poljak et al. 2000).

In November 2004 we installed the TM 71 device in the NW part of Idrija Fault, where good exposure of the main fault zone was found in the Učja valley near Bovec. The whole fault zone is there more than $1 \mathrm{~km}$ wide and was divided into outer and inner fault zone by Čar \& Pišljar (1993). The TM 71 instrument is installed on a prominent crack in the central part of the inner fault zone, which cuts the $50 \mathrm{~m}$ high wall of a canyon.

In the first 10 months of measurements a clear trend of left-lateral horizontal displacements $y=+0.54$ $\mathrm{mm}$ /year was developed (Fig. 4). It was followed by an outlying measurement at the beginning of 2006. It was most probably caused by a mechanical impact on the instrument (fallen rock or ice), because the displacement completely recovered in the next months. The same leftlateral trend continued, but the rate was slightly diminishing with time. The average displacement rate for the first two and a half years of measurements is $y=+0.31$ $\mathrm{mm} /$ year and for three and a half years $\mathrm{y}=+0.26 \mathrm{~mm} /$ year. On the other hand a very small rate of $z=+0.06 \mathrm{~mm} /$ year (downslip of SW block) was established on the vertical z-axis. The $\mathrm{x}$-axis (opening or closing of the crack) shows clear seasonal effects, which are in good correla-

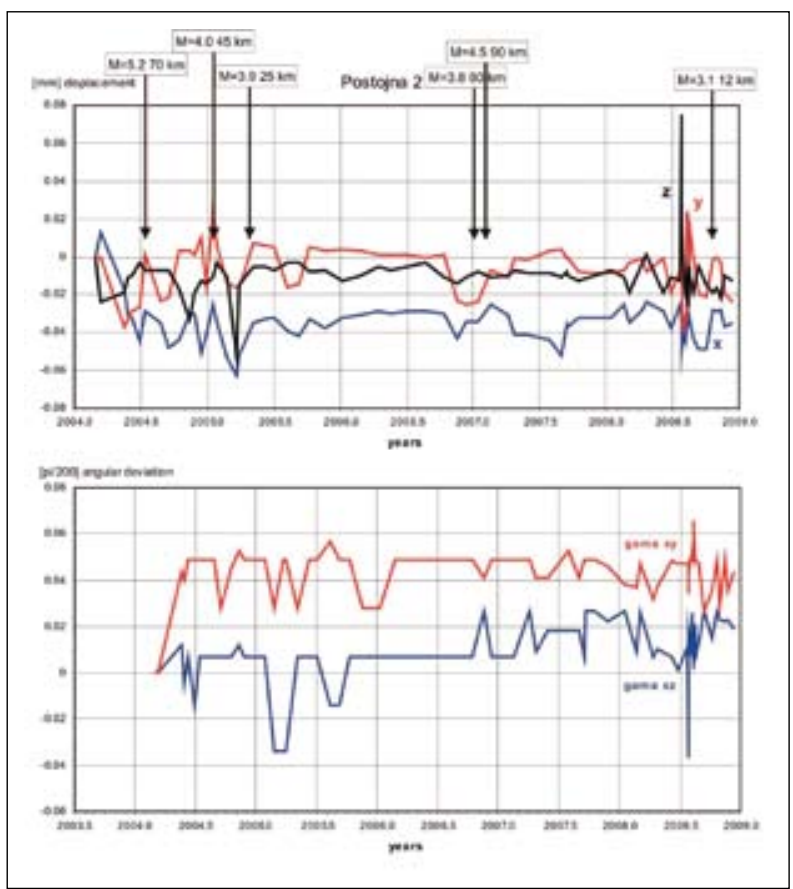

Fig. 8: Relative displacements ( $+x$ compression $(-x$ extension), $+y$ sinistral horizontal movement $(-y$ dextral) and $+z$ down-slip of northern block (-z uplift)) and angular deviation detected with TM 71 exstensometers for Postojna 2 with strongest earthquakes (magnitude and distance of epicentre, Tab. 2).

tion with recorded temperatures. In the same period no clear trend in angular deviation was developed in both planes although there is a visible anomaly in mid-2007, which was later almost completely recovered.

Relative movement between blocks shows left-lateral horizontal displacement with minor downslip component. This is an unexpected result, because Idrija Fault is considered as a dextral strike-slip fault (Čar \& Pišljar 1993). There are clear geological evidences of dextral displacement for the geological history, but for recent times no direct proofs are available. Therefore the dextral strike-slip movement was mainly inferred from the orientation of principal stress axis, which is oriented in N-S direction and from fault plane solutions of two stronger earthquakes that occurred on parallel Ravne Fault. Observed left-lateral displacement should be therefore explained by local permutation of stress direction inside the very complex fault zone (Kavčič 2006). The amplitude of the observed slip rate of $0.3-0.5 \mathrm{~mm} /$ year is in agreement with regional GPS displacement rates in W Slovenia, which are up to $2 \mathrm{~mm} /$ year. But the GPS points were too sparse in this study (Vrabec et al. 2006) to establish the sense of displacement along individual faults; only regional deformation rates can be determined. In any case longer observations and detailed tectonic map- 
ping of the complex Idrija Fault cross-section in the Učja valley are necessary to understand the relations between different cracks observed in outer and inner fault zones.

\section{Raša Fault}

Raša Fault is located approximately $25 \mathrm{~km} \mathrm{SW}$ from the Idrija Fault. It can be clearly traced in a length of $50 \mathrm{~km}$ from $\mathrm{N}$ of Nova Gorica to the Snežnik thrust at Ilirska Bistrica (Fig. 1). The main surface expressions of this fault are: almost straight valley of the Raša river and the topography around Vremščica Mountain. The fault has a multiphase kinematic development, which is typical for most regional faults in External Dinarides (Jurkovšek et al. 1996). The seismicity in the vicinity of the Raša fault is concentrated mainly in the Snežnik Mt. area at its SE termination. Hypocenters of the earthquakes in this area define a steeply NE dipping fault plane (Michelini et al. 1998).

We explored the whole trace of the Raša Fault to find a suitable location for installation of TM 71 extensometer. In spite of its clear expression in the topography we recognized that there are very few good exposures. The best location was found at the foot of Vremščica Mt., on its SE side, near Košana. There are two abandoned quarries in the Upper Cretaceous limestone situated exactly at the fault trace. The lower one has been abandoned for more than 15 years and will remain closed. Therefore, it provides a suitable place for crack gauge measurements. The contact between Upper Cretaceous limestone to the NE and Palaeocene Kozina limestone to the SE (Buser et al. 1967) is exposed in this quarry, separated by the main fault zone, which is approximately $10 \mathrm{~m}$ wide. Therefore, it was not possible to install the instrument in the main fault plane, but we selected a parallel crack in the exposed wall of the quarry built of Cretaceous limestone. The measurements started in November 2004.

In the first 1.5-3.5 years the monitoring site established an average reverse uplift of hanging wall (SW) block of $\mathrm{z}=-0.16 \mathrm{~mm} /$ year and left-lateral displacement of $y=+0.16 \mathrm{~mm} /$ year (Fig. 5). Short-term (9 months) vertical displacements reached the value of $\mathrm{z}=-0.53 \mathrm{~mm} /$ year. In the period from mid-2007 to mid-2008 the reverse uplift changed to $\mathrm{z}=+0.37 \mathrm{~mm} /$ year down-slip of SW block, while y-axis shows no clear displacement from beginning of 2007. The $\mathrm{x}$-axis (opening or closing of the crack) shows clear seasonal effects, which are in good correlation with recorded temperatures. Following no clear trend in angular deviations, which were observed during first three years of measurement, during the last year a clear trend on xy-plane was developed.

The established oblique sense of displacement is only partly in agreement with geological and seismological observations. In comparison of our measurements with other data it must be considered that the TM 71 instrument was not installed on the main fault plane, but on one of near parallel cracks. Local variation of the stress axis can therefore explain the observed differences. Focal mechanisms of some stronger earthquakes in the active zone of Snežnik Mt., SE of the monitoring site, also indicate strike-slip and reverse movement (Poljak et al. 2000). On the other hand Jurkovšek et al. (1996) claim that the fault has undergone multiphase development from reverse over gravitational to the final strikeslip movement. From repeated geodetic levelling line measurements along the Sečovlje-Bled polygon (Rižnar et al. 2007) only vertical component of relative displacement was revealed due to the limitation of the method. From this data set the area between Divača and Raša Fault shows an uniform uplift of the order of $2 \mathrm{~mm}$ /year in relation to the reference point in Sečovlje, but close to the Raša Fault anomalous values were obtained as low as $1 \mathrm{~mm} /$ year. For the area NE of the Raša Fault the relative vertical uplift is again around $2 \mathrm{~mm} /$ year. No 3D terrestic geodetic or GPS data are available in the area to compare the sense of the movement along this fault.

\section{Kneža Fault}

Kneža Fault is a dextral strike-slip fault located in the Julian Alps inbetween Idrija Fault to the SW and Ravne Fault to the NE (Fig. 1). It can be traced for at least $30 \mathrm{~km}$ between the Bovec basin in the NW and Idrijca valley and further to the SE. There are no direct proofs of activity of Kneža Fault, but nearby Ravne Fault was proved active (Kastelic et al. 2008) by two recent strong earthquakes, $\mathrm{Mw}=5.6$ in 1998 and $\mathrm{Mw}=5.2$ in 2004 (Gosar 2007b). Although carefully inspected we did not find a suitable place to install TM 71 extensometer on the Ravne Fault, because it extends mainly across a high mountain area with difficult access. Therefore we decided to monitor parallel Idrija and Kneža Faults, which are both supposed to be active. On Kneža Fault the TM 71 device was installed in autumn 2006 near village ZadlazČadrg at the contact of the highly fractured fault zone with adjacent compact rock.

During two years of monitoring a clear horizontal right-lateral displacement $\mathrm{y}=-0.06 \mathrm{~mm} /$ year was established (Fig. 6). Less stable is the vertical movement which shows average displacement rate of $\mathrm{z}=-0.07 \mathrm{~mm} /$ year, which corresponds to the uplift of the SW block. The $\mathrm{x}$-axis (opening or closing of the crack) shows clear seasonal effects, which correlate well with temperatures. No clear angular deviations were established so far, although some minor rotation is visible in xz-plane.

The measured oblique displacement (dextral strikeslip with reverse component) is in agreement with geological setting and sense of displacement established 
from fault-plane solutions for the two earthquakes on Ravne Fault (1998 and 2004) and majority of their aftershocks. From the distribution of aftershock hypocenters around Ravne Fault (Kastelic at al. 2008) we cannot exclude that some of them occurred on Kneža Fault. The rate of displacements observed so far on Kneža Fault is considerably smaller than the rates established on Idrija and Raša Faults.

\section{UNDERGROUND MONITORING}

\section{Postojnska Jama}

In Postojnska Jama the Dinaric-oriented fault zone (NW-SE) has been monitored for micro-deformations with two TM 71 instruments since 2004. This longest Slovene karst cave $(20 \mathrm{~km})$ is developed in Upper Cretaceous limestones. Postojna 1 site is situated at $560 \mathrm{~m}$ above sea and Postojna 2 at $526 \mathrm{~m}$. On Postojna 1 site TM 71 is installed in the contact between fault plane, representing the Velika Gora collapse chamber's northern wall, and a 2x2x1 m collapse block of limestone. Postojna 2 site is an artificially enlarged narrow natural cave passage that looks to have good contact with $60 \mathrm{~m}$ distant surface. From a speleological point of view, Postojna 1 site is located on the top of the biggest cave's collapse chamber and Postojna 2 in a narrow (1-1.5 m wide) artificially enlarged cave passage. For both monitoring sites stable climate conditions are typical. At Postojna 1 the temperature throughout the year is $9.5-11^{\circ} \mathrm{C}$ and at Postojna 2 it is $9-11^{\circ} \mathrm{C}$.

The movements obtained from two, $260 \mathrm{~m}$ distant, monitoring sites in Postojnska Jama are small (Figs. 7 and 8). We got some interesting peaks (maximum for $0.08 \mathrm{~mm}$ on both monitoring sites) and very stable periods with almost no movements (Postojna 1 and $2 \mathrm{y}$-axis from the end of 2005 during 2006) what supports our hypothesis of monitoring the real tectonic deformations, excluding influence of seasonal temperature changes and influence of karst water oscillations.

Responses to Earth's stress changes regarding $\mathrm{x}, \mathrm{y}$ and $\mathrm{z}$-axes are not the same on two monitoring sites in the cave, even though monitoring the same fault zone. Generally we detect small tectonic deformations, dextral horizontal movement of $0.05 \mathrm{~mm}$ in 5 years (2004-2008) for Postojna 1 (Fig. 7) and extension of $0.03 \mathrm{~mm}$ in 5 years (2004-2008) for Postojna 2 (Fig. 8).

Within the y curve on Postojna 1 we registered the biggest movement $\left(10^{\text {th }}\right.$ November 2004 to $15^{\text {th }}$ December 2004) of $-0.08 \mathrm{~mm}$ (dextral horizontal movement). And on Postojna $2 \mathrm{z}$-axis (24-25 ${ }^{\text {th }}$ July 2008) there was the biggest vertical movement of $-0.08 \mathrm{~mm}$.

In Postojnska Jama the movements generally return back to the previous position. The only well expressed permanent step (dextral horizontal movement) remained on Postojna 1 y-axis after August 2005. Gentle extension of $0.02 \mathrm{~mm}$ in 5 years can be seen at Postojna $1 \mathrm{x}$-axis and vertical movement that does not exceed 0.02 $\mathrm{mm}$ in 5 years. The results show that the collapse blocks cemented by flowstone in Velika Gora chamber are very stable.

Postojna 2 site showed the highest movements between July and September 2008, horizontal movements of $0.06 \mathrm{~mm}$ maximum, changing from sinistral to dextral and returning back to the null position, and the best expressed peak on $\mathrm{z}$-axis of $0.08 \mathrm{~mm}$ (subsidence of northern block).

Due to some different behaviour between Postojna 1 and 2 monitoring sites we assume that the monitoring shows some local deformations as well. This is in accordance with Kontny et al. (2005) who described probable movement of a particular rock-block at monitoring sites in Polish Sudeten. But on the other hand at least one axis, although different, is comparable between two monitoring sites in Postojnska Jama (Šebela et al. 2009). Additionally we envisage the detection of general displacements due to changes in regional stress regime, as was described by Stemberk et al. (2008b) in Upper Rhein graben during longer period.

Differences in displacements between two monitoring sites of Postojnska Jama can be explained by complex geological structure of the cave. Postojna 1 is situated in the biggest collapse chamber in the cave and Postojna 2 is situated in an artificially enlarged small natural passage. Between both sites the studied Dinaric Fault Zone is cut by cross-Dinaric Fault Zone (NE-SW) that might transmit some deformations causing differences between Postojna 1 and 2 sites (Gosar et al. 2007).

Although Postojnska Jama is not situated on a seismically very active area, it is close to Snežnik Mountain area, which is one of the most active zones in Slovenia. The results of $3 \mathrm{D}$ monitoring are showing good stability of both monitoring sites with occasional well-expressed peaks connected with changes in Earth's stress field and are in this sense important for understanding the transition zone between Predjama and Idrija Faults.

\section{Pološka Jama}

The cave is developed in Upper Triassic bedded Dachstein limestone $\mathrm{T}_{3}^{2+3}$ (Buser 1986). Its upper entrance is situated at $1,249 \mathrm{~m}$ and lower entrances at $730 \mathrm{~m}$ above sea on the eastern slope of Krn Mountains $(2,244 \mathrm{~m})$. Cave's passages, being $10,800 \mathrm{~m}$ long and $704 \mathrm{~m}$ deep, are situated 250-800 m south from Ravne Fault. TM 71 is placed between two slipped limestone beds (dip direction $120^{\circ}$ and dip angle $40^{\circ}$, Fig. 2 ), about $300 \mathrm{~m}$ south from Ravne Fault and about $50 \mathrm{~m}$ inside the 
cave from the eastern of the lower entrances. About 200 $\mathrm{m}$ below the monitoring site the very important regional structure of Julian Alps thrust (SE-verging and parallel to monitored bedding-plane) within Southern Alps geotectonic unit (Poljak 2000) can be found. According to Poljak (2000) the contact between geotectonic units of Southern Alps over the Internal Dinarides is situated about $4.5 \mathrm{~km}$ south from our monitoring site.

According to Rižnar et al. (2007) the Southalpine Front (Southern Alps according to Poljak 2000) is the most active structure in western Slovenia in the sense of vertical movement. A maximum of $7 \mathrm{~mm} /$ year of difference in the relative vertical movement rate along the whole levelling profile Sečovlje-Bled was observed. The activity of the Julian Alps thrust is also obvious, but minor compared with Southalpine Front (Rižnar et al. 2007). In the sense of Milanič et al. (2009) recent tectonic activity was determined for Julian Alps thrust and not clearly for Southalpine Front.

Results of displacements for Pološka Jama are preliminary. Because of uphill access across 1998 co-seismic rockfalls, only three measurements were accomplished in the second half of 2008. To get representative results at least one-year long monitoring is obliged. But previous monitoring on other sites (Šebela et al. 2005) showed comparative results between short and long-term monitoring as well. The highest displacement was detected in $\mathrm{x}$-axis, being of $0.08 \mathrm{~mm}$ and representing horizontal

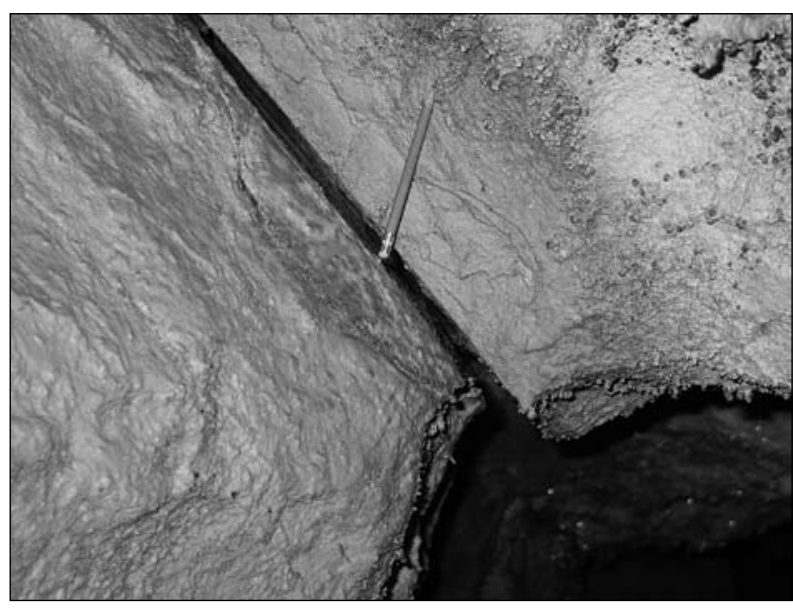

Fig. 9: Pološka Jama, displaced cave passage along bedding-plane (Photo: S. Šebela).

opening between two limestone beds in the period of half a year. The activity of bedding-plane is visible also in a cave passage that is displaced for about $5 \mathrm{~cm}$ (Fig. 9). Taking into account that cave temperature at the monitoring site varies $\left(2^{\text {nd }}\right.$ November $2008=6^{\circ} \mathrm{C}$ and $17^{\text {th }}$ February $2009=1^{\circ} \mathrm{C}$ ), the observed displacement can be due to temperature influence as well. In Pološka Jama active displacements are connected with Ravne Fault or/ and Julian Alps thrust.

\section{CORRELATION WITH SEISMIC ACTIVITY}

Some ideas in paralleling well-expressed micro-movements detected by TM 71 with earthquakes have been described by several authors (Košták et al. 2007; Stemberk et al. 2008a; Briestenský et al. 2007; Kontny et al. 2005; Shanov 1993). According to the Košták's hypothesis a strong earthquake would respond to temporary changes in the Earth's crust stress field detectable in the readings of sensitive extensometer instruments (Košták 1998, 2002).

We compared seismic activity in wider region of W Slovenia with observed displacements detected by all TM 71 extensometers. First we found that the frequency of taking readings at all surface monitoring sites (Idrija, Raša and Kneža Faults) was too low for reliable correlation. For Kneža Fault and Pološka Jama the readings were also taken for too short time period to allow correlation with seismic activity. Therefore, we concentrated on both monitoring sites in Postojnska Jama, where readings were taken more frequently (on average once a month). Around 25 stronger earthquakes from the seismic catalogue (EARS 2008), which occurred between 2004 and 2009, were considered for comparison with microdeformations. Most of them are events with magnitude greater than 3.0 and epicentral distances from $12 \mathrm{~km}$ to $90 \mathrm{~km}$. For very close epicentres $(<15 \mathrm{~km})$ also some weaker events were analyzed. Data of stronger earthquakes with epicentral distances from Postojnska Jama are summarised in Tab. 2.

Owing to general small tectonic deformations registered in Postojnska Jama, it is difficult to find some very good coincidences between earthquakes and tectonic movements. However, some sharp peaks coincide with earthquake occurrences. The best examples are:

- Krn (12 ${ }^{\text {th }}$ July 2004) earthquake M=5.2 (Šebela et al. 2005),

- Cerkno ( $14^{\text {th }}$ January 2005) earthquake $M=4.0$ (Postojna $2 \mathrm{x}$ and $\mathrm{z}$, Postojna $1 \mathrm{y}$ ), 


\begin{tabular}{|l|l|l|l|l|}
\hline Date & Magnitude & Location & Distance & Depth $(\mathbf{k m})$ \\
\hline $12 / 07 / 2004$ & 5.2 & Krn & $70 \mathrm{~km} \mathrm{NW}$ & 13 \\
\hline $14 / 01 / 2005$ & 4.0 & Cerkno & $45 \mathrm{~km} \mathrm{~N}$ & 20 \\
\hline $24 / 04 / 2005$ & 3.9 & Ilirska Bistrica & $25 \mathrm{~km} \mathrm{~S}$ & 17 \\
\hline $01 / 01 / 2007$ & 3.8 & Feistritz (Austria) & $80 \mathrm{~km} \mathrm{~N}$ & 16 \\
\hline $05 / 02 / 2007$ & 4.5 & Drežnica (Croatia) & $90 \mathrm{~km} \mathrm{~S}$ & 10 \\
\hline $21 / 10 / 2008$ & 3.1 & Pivka & $12 \mathrm{~km} \mathrm{~S}$ & 16 \\
\hline
\end{tabular}

Tab. 2: Basic data on stronger earthquakes, which occured during TM 71 monitoring with epicentral distances from Postojnska Jama.

- Ilirska Bistrica (24 $4^{\text {th }}$ April 2005) earthquake $M=3.9$ (Postojna $2 \mathrm{x}$ and $\mathrm{z}$ ),

- Pivka (21 $1^{\text {st }}$ October 2008) $\mathrm{M}=3.1$ earthquake followed by Pivka (22 ${ }^{\text {nd }}$ October 2008$) \mathrm{M}=2.3$ earthquake (Postojna $2 \mathrm{z}$ and $\mathrm{y}$ ).

On Postojna $2 \mathrm{x}$-axis the extension is followed by compression, at the end of which (Krn, Cerkno, Ilirska
Bistrica) earthquakes occurred. On Postojna 2 z-axis Krn, Cerkno, Ilirska Bistrica and Pivka earthquakes coincide with highest peaks. On Postojna 1 and $2 y$-axes dextral horizontal movement is followed by sinistral movement at the end of which there is partially good coincidence with Krn, Cerkno and Ilirska Bistrica earthquakes.

At the end of July 2008 the highest peak on Postojna 2 z-axis (Fig. 8) was detected and about 2.5 months later Pivka earthquakes with the strongest $\mathrm{M}=3.1$ occurred only $12 \mathrm{~km}$ south from Postojna 2 monitoring site. Additional studies are necessary to better understand such situations.

\section{CONCLUSIONS}

Regarding some ten-years monitoring with TM 71 in other countries (Koš̀ták et al. 2007; Kontny et al. 2005) and regarding the data obtained from Slovenia, we determined to monitor micro-tectonic deformations of selected fault zones in Slovenia, transmitting the changes in stress/strain conditions that can coincide with stronger earthquakes.

Two surface monitoring sites at Idrija and Raša Faults show clear micro-deformations. The average lateral displacement measured on Idrija Fault in Učja valley is $0.26 \mathrm{~mm} /$ year. Short-term rates were even greater and reached $0.54 \mathrm{~mm} /$ year. Raša Fault monitoring site established first an average uplift of SW block for $0.16 \mathrm{~mm} /$ year and left-lateral displacement of $0.16 \mathrm{~mm} /$ year. It was followed by down-slip of the same block at the rate of $0.37 \mathrm{~mm} /$ year.

In two Slovene karst caves moderate micro-displacements are detected. Postojnska Jama is very stable with small tectonic deformations, being general dextral horizontal movement of $0.05 \mathrm{~mm}$ in 5 years for Postojna 1 and extension of $0.03 \mathrm{~mm}$ in 5 years for Postojna 2 , with two significantly expressed peaks of $0.08 \mathrm{~mm}$ (Postojna 1-y and Postojna 2-z). Results of Pološka Jama are preliminary, showing $0.08 \mathrm{~mm}$ in half a year in $\mathrm{x}$-axis (opening of bedding-plane $120^{\circ} / 40^{\circ}$ ).

All surface monitoring sites show clear seasonal effects on $\mathrm{x}$-axis (opening or closing of the crack), which are in good correlation with recorded temperatures. Sea- sonal effects are not expected and are also not visible on two monitoring sites in Postonjska Jama where the temperature is relatively constant throughout the year (9$11^{\circ} \mathrm{C}$ ). Relatively small extensions can be seen therefore on this two sites.

The observed displacement rates of up to $0.5 \mathrm{~mm} /$ year along monitored active faults are consistent with the regional deformation rate in W Slovenia established from GPS measurement, which is of the order of $2 \mathrm{~mm}$ /year (Vrabec \& Fodor 2006; Weber et al. 2006). According to the long-term geological data, regional Dinaric faults in W Slovenia express dextral strike-slip movements. There were no 3D terrestic geodetic measurements performed along these faults to establish the recent movements, whereas the points used in some GPS project were too sparse to determine the sense of movement along individual fault. From them it was possible to derive only the regional deformation rate. Fault plane solutions are available and also show dextral strike-slip motion for recent earthquakes on Ravne Fault, which is not equipped with TM 71 instrument, because we did not find yet a suitable location in high mountain environment for its installation. They are available also for the SE part of the Raša Fault where they show reverse and strike-slip movement. Therefore, direct comparison of micro-deformation monitoring on individual cracks inside fault zones and other data can be done to very limited extent. Left-lateral displacement on Idrija Fault can be explained 
by structural anisotropy and local permutation of principal stress axis inside complex fault zone. Oblique displacement with left-lateral component on the Raša Fault is partly in agreement with fault plane solutions, but according to regional geological data right-lateral movements are expected.

More important than correlation of micro-deformation monitoring with regional geology and earthquake would be a correlation with detail 3D terrestic geodetic (not only levelling, which is available along some sec- tions) or very dense GPS measurements that will allow judgment on the sense and rate of movement along individual fault. Unfortunately, none of them are available yet in the area. Micro-deformation monitoring with TM 71 instruments therefore provides the first quantification of recent active tectonic deformations within fault zones of Idrija and Raša Faults and in Postojnska Jama. Observed displacement rates of up to $0.5 \mathrm{~mm}$ /year are already significant for seismic hazard studies.

\section{ACKNOWLEDGEMENTS}

The TM 71 monitoring in Slovenia started within the COST 625 project (3D monitoring of active tectonic structures) and is continuing within Slovenia-Czech bilateral projects (BI-CZ/06-07-011 and BI-CZ/08-09-015). The authors want to thank Mojca Kavčič, Janez Mulec, Andrej Fratnik, Brane and Matjaž Čuk for taking data on the field. Thanks to Tomaš Nydl, Lubomir Petro, Josef Hok, Miloš Briestenský, Janez Turk, Janez Mulec, Mitja Prelovšek, Andrej Fratnik, Andreea Oarga and Monika Hladká for their help during installation of instruments. Thanks to Trevor Shaw for editing the English text.

\section{REFERENCES}

Borre, K., Cacon, S., Cello, G., Kontny, B., Košták, B., Likke Andersen, H., Moratti, G., Piccardi, L., Stemberk, J., Tondi, E. \& V. Vilimek, 2003: The COST project in Italy: analysis and monitoring of seismogenic faults in the Gargano and Norcia areas (central-southern Apennines, Italy).- Journal of Geodynamics, 36, 3-18.

Briestenský, M., Stemberk, J. \& L. Petro, 2007: Displacements registered around the 13 March 2006 Vrbové earthquake $\mathrm{M}=3.2$ (Western Carpathians).- Geologica Carpathica, 58, 5, 487-493.

Buser, S., Grad, K. \& M. Pleničar, 1967: Osnovna geološka karta SFRJ, list Postojna, 1:100000.- Zvezni geološki zavod, Beograd.

Buser, S., 1986: Osnovna geološka karta SFRJ, list Tolmin in Videm, 1:100000.- Zvezni geološki zavod, Beograd.

Cunningham, D., Tansey, K., Gosar, A. \& V. Kastelic, 2006: Application of airborne LiDAR to mapping seismogenic faults in forested mountainous terrain, southeastern Alps, Slovenia.- Geophisical Research Letters, vol. 33, L20308, doi:10.1029/ 2006 GL027014.
Čar, J. \& M. Pišljar, 1993: Cross section of the Idrija fault and the course of the Učja valley regarding the fault structures.- Rudarsko-metalurški zbornik, 40, 1-2, 79-91.

EARS 2008: Earthquake catalogue for the years 567-2008.Environmental Agency of the Republic of Slovenia, Seismology and geology office.

Fitzko, F., Suhadolc, P., Aoudia, A. \& G.F. Panza, 2005: Constraints on the location and mechanism of the 1511 Western-Slovenia earthquake from active tectonics and modeling of macroseismic data.- Tectonophysics, 404, 77-90.

Jurkovšek, B., Toman, M., Ogorelec, B., Šribar, L., Drobne, K., Poljak, M. \& L. Šribar, 1996: Geological map of the southern part of the Trieste-Komen plateau.- Geological Survey of Slovenia, pp. 143, Ljubljana.

Gosar, A., 2007a: Monitoring of micro-deformations along Idrija and Raša faults in W Slovenia.- Geologija, 50, 1, 45-54.

Gosar, A., 2007b: Microtremor HVSR study for assessing site effects in the Bovec basin (NW Slovenia) related to $1998 \mathrm{Mw} 5.6$ and $2004 \mathrm{Mw} 5.2$ earthquakes.- Engineering Geology, 91, 178-193. 
Gosar, A., Šebela, S., Košták, B. \& J. Stemberk, 2007: Micro-deformation monitoring of active tectonic structures in W Slovenia.- Acta Geodyn. Geomater., 4, 1, 87-98.

Kastelic, V., Vrabec, M., Cunningham, D. \& A. Gosar, 2008: Neo - Alpine structural evolution and present day tectonic activity of the eastern Southern Alps: the case of the Ravne Fault, NW Slovenia.- Journal of structural geology, 30, 8, 963-975.

Kavčič, M., 2006: Displacement measurements along some faults in $W$ Slovenia by extensiometers.- Graduation thesis. University of Ljubljana, pp. 118.

Komac, M. \& M. Bavec, 2007: Application of PSInSAR for observing the vertical component of the recent surface displacements in Julian Alps.- Geologija, 50, 1, 97-110.

Kontny, B., Cacoń, S., Košták, B. \& J. Stemberk, 2005: Methodic analysis of data obtained by monitoring micro-tectonic movements with TM-71 crack gauges in the Polish Sudeten.- Acta Geodyn. Geomater., 2, 3, 57-67.

Košták, B., 1969: A new device for in-situ movement detection and measurement.- Exp. Mechanics, 9, 8, 374-379.

Košták, B., 1977: Terčové měřidlo TM-71 a jeho užití pro měření velmi pomalých pohybů na poruchách a trhlinách.- Inž. Stavby, 25, 5, 213-218.

Košták, B., 1991: Combined indicator using Moiré technique.- In: Sorum, G. (ed.) Proc. $3^{\text {rd }}$ Int. Symp. on Field Measurements in Geomechanics, $9^{\text {th }}-11 \mathrm{t}^{\mathrm{h}}$ Sept. 1991, Oslo. Balkema, 1, 53-60, Rotterdam, Brookfield.

Košták, B., 1998: Evidence of active tectonic movements in Krušné Hory Mts. (NW Bohemia).- Journal of the Czech Geological Society, 43, 3, 287-297.

Košták, B., 2002: Cycles, trends, impulses in rock movement monitoring.- In: Rybář, J. et al. (eds.) Landslides. Swets \& Zeitlinger, pp. 603-609, Lisse.

Košták, B., Cacoń. S., Dobrev, N.D., Avramova-Tacheva, E., Fecker, E., Kopecký, J., Petro, L., Schweizer, R. \& A.A. Nikonov, 2007: Observations of tectonic microdisplacements in Europe in relation to the Iran 1997 and Turkey 1999 earthquakes.- Izvestiya Physics of the Solid Earth, 43, 6, 503-516.

Mąkolski, K., Cacoń, S., Jamroz, O., Košták, B. \& M. Kaczałek, 2008: Investigations regarding Bear cave massif (Lower Silesia) long-term stability.- Acta carsologica, 37, 2-3, 279-290.

Márton, E., Čosović, V., Drobne, K. \& A. Moro, 2003: Palaeomagnetic evidence for Tertiary counterclockwise rotation of Adria.- Tectonophysics, 377, 143156.
Michelini, A., Živčič, M. \& P. Suhadolc, 1998: Simultaneous inversion for velocity structure and hypocenters in Slovenia.- J. Seismol., 2, 257-265.

Milanič, B., Vrabec, M., Oštir, K., Komac, M. \& M. Bavec, 2009: Ocena recentnih tektonskih premikov $\mathrm{v}$ severozahodni Sloveniji na podlagi primerjave PSInSAR podatkov in nivelmanske izmere.Geološki zbornik, 20, 19.Meeting of Slovenian Geologists, 102-106.

Placer, L., 2008: Principles of the tectonic subdivision of Slovenia.- Geologija, 51, 2, 205-217.

Poljak, M., 2000: Structural-tectonic map of Slovenia, 1:250000, compiled from the Geological Map of SFR Yugoslavia 1:100000.- Geološki Zavod Slovenije, Mladinska knjiga, Ljubljana.

Poljak, M., Živčić, M. \& P. Zupančič, 2000: The seismotectonic charateristics of Slovenia.- Pure and Applied Geophysics, 157, 37-55.

Ribarič, V., 1979: The Idrija earthquake of March 26, 1511 - a reconstruction of some seismological parameters.- Tectonophysics, 53, 315-324.

Rižnar, I., Koler, B. \& M. Bavec, 2007: Recent activity of the regional geologic structures in western Slovenia.- Geologija, 50, 1, 111-120.

Shanov, S., 1993: Medium-time earthquake prediction based on tectonic fault zone displacement data.Acta Montana AS CR, series A, 4, 52-62.

Stemberk, J., Košták, B. \& V. Vilimek, 2003: 3D monitoring of active tectonic structures.- Journal of Geodynamics, 36, 1-2, 103-112.

Stemberk, J., Briestenský, M. \& N. Jurková, 2008a: Displacements registered in the selected caves of the Bohemian Massif.- Speleoforum 2008, 27, 141-144.

Stemberk, J., Fecker, E., Košták, B. \& J. Rybář, 2008b: Tectonic movements detected recently in the Upper Rheingraben.- In: Triantafyllidis, T. (ed.) Grundlagen und Anwendungen der Geomechanik, GKK 08-Geomechanik Kolloquium Karlsruhe 2008, Teil 1 - Felsmechanik, Fels- und Tunnelbau, Karlsruhe.Veröffentlichungen des Institutes für Bodenmechanik und Felsmechanik der Universität Fridericiana in Karlsruhe, 187-198, Karlsruhe.

Šebela, S., 2005: Monitoring of active tectonic structures - Project COST 625.- Acta carsologica, 34, 2, 471488.

Šebela, S., 2009: 3D monitoring of active tectonic movements in Slovene karst caves.- Geološki zbornik, 20, 19.Meeting of Slovenian Geologists, 152-155. 
Šebela, S. \& A. Gosar, 2005: Začetek meritev premikov ob prelomih v zahodni Sloveniji s 3D estenziometri TM 71.- In: Kozmus, K. \& M. Kuhar (eds.) Raziskave s področja geodezije in geofizike, 10. strokovno srečanje Slovenskega združenja za geodezijo in geofiziko, 13. januar 2005, Ljubljana. Univeza v Ljubljani, Fakulteta za gradbeništvo in geodezijo, 3745, Ljubljana.

Šebela, S., Gosar, A., Košták, B. \& J. Stemberk, 2005: Active tectonic structures in the $\mathrm{W}$ part of Slovenia - Setting of micro-deformation monitoring net.Acta Geodyn. Geomater., 2, 1, 137, 45-57.

Šebela, S., Košták, B., Mulec, J. \& J. Stemberk, 2008: Merjenje tektonskih premikov v Postojnski jami.- In: Kuhar, M. (ed) Raziskave s področja geodezije in geofizike 2007, 13. strokovno srečanje SZGG, 17. januar 2008, Ljubljana. Univeza v Ljubljani, Fakulteta za gradbeništvo in geodezijo, 21-26, Ljubljana.

Šebela, S., Turk, J., Mulec, J., Košták, B. \& J. Stemberk, 2009: Statistical evaluation of the 3D monitoring of displacements of Dinaric Fault Zone in Postojna Cave, Slovenia.- Acta Geodyn. Geomater., 6, 2, 154, 163-176.
Vrabec, M. \& L. Fodor, 2006: Late Cenozoic tectonics of Slovenia: Structural styles at the North-Eastern corner of the Adriatic microplate.- In: Pinter, N. et al. (eds.) The Adria Microplate: GPS Geodesy, Tectonics and Hazards. Proceedings of the NATO Advanced Research Workshop on The Adria Microplate, NATO Sciences Series, VI, Earth and Environmental Sciences, 61, pp. 151-168, Springer.

Vrabec, M., Pavlovčič Prešeren, P. \& B. Stopar, 2006: GPS study (1996-2002) of active deformation along the Periadriatic fault system in northeastern Slovenia tectonic model.- Geol. Carpath., 57, 1, 57-65.

Weber, J., Vrabec, M., Stopar, B., Pavlovčič Prešeren, P. \& T. Dixon, 2006: The PIVO-2003 experiment: a GPS study of Istria peninsula and Adria microplate motion, and active tectonics in Slovenia.- In: Pinter, N. et al. (eds.) The Adria Microplate: GPS Geodesy, Tectonics and Hazards. Proceedings of the NATO Advanced Research Workshop on The Adria Microplate, NATO Sciences Series, VI, Earth and Environmental Sciences, 61, pp. 305-320, Springer. 